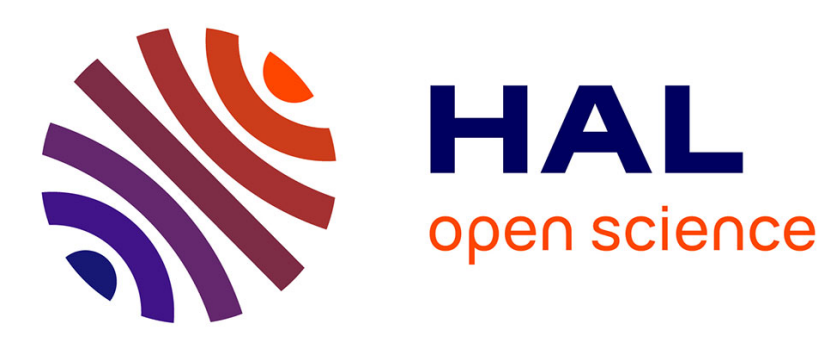

\title{
Asymmetric Dipyrrin and F-BODIPYs Conjugated to Terminal Alkynes and Alkenes
}

Carlotta Figliola, Katherine N Robertson, Sarah Greening, Alison Thompson

\section{To cite this version:}

Carlotta Figliola, Katherine N Robertson, Sarah Greening, Alison Thompson. Asymmetric Dipyrrin and F-BODIPYs Conjugated to Terminal Alkynes and Alkenes. Journal of Organic Chemistry, 2017, 82 (13), pp.7059-7064. 10.1021/acs.joc.7b01129 . hal-01588477

\section{HAL Id: hal-01588477 \\ https://hal.science/hal-01588477}

Submitted on 14 Nov 2021

HAL is a multi-disciplinary open access archive for the deposit and dissemination of scientific research documents, whether they are published or not. The documents may come from teaching and research institutions in France or abroad, or from public or private research centers.
L'archive ouverte pluridisciplinaire HAL, est destinée au dépôt et à la diffusion de documents scientifiques de niveau recherche, publiés ou non, émanant des établissements d'enseignement et de recherche français ou étrangers, des laboratoires publics ou privés. 


\title{
Asymmetric dipyrrin and $\boldsymbol{F}$-BODIPYs conjugated to
}

\section{terminal alkynes and alkenes}

Carlotta Figliola, ${ }^{a}$ Katherine N. Robertson, ${ }^{b}$ Sarah Greening ${ }^{a}$ and Alison Thompson*a

a Department of Chemistry, Dalhousie University, PO BOX 15000, Halifax, NS, B3H 4R2,

Canada

${ }^{\mathrm{b}}$ Department of Chemistry, Saint Mary's University, Halifax, NS, B3H 3C3, Canada

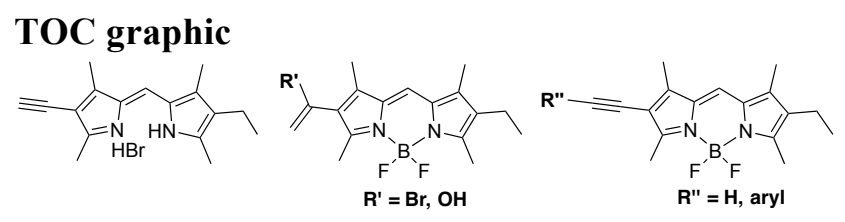

\begin{abstract}
An asymmetric meso- $H$ dipyrrin featuring a conjugated terminal alkyne substituent was converted to its corresponding difluoro boron complex and the extent of $\pi$-conjugation extended using Sonogashira cross-coupling. Treatment of the alkyne-substituted dipyrrin with $\mathrm{BF}_{3} \bullet \mathrm{OEt}_{2}$ and $\mathrm{NEt}_{3}$ revealed the reactivity of the conjugated terminal alkyne towards Lewis-activated electrophilic substitution, and led to the isolation of $F$-BODIPYs bearing terminal bromovinyl and enol substituents.
\end{abstract}

4,4'-Difluoro-4-bora-(3a,4a)-diaza-s-indacenes (F-BODIPYs $)^{1}$ are popular courtesy of their robustness in chemical and physiological environments, tunable nanosecond fluorescence lifetime, negligible triple-state population and high quantum yield. ${ }^{2-7}$ Indeed, the electronic 
properties of BODIPYs have recently been exploited in chromogenic and $\mathrm{pH}$ probes in biomolecular environments, ${ }^{8,9}$, drug delivery agents, ${ }^{10,11}$ fluorescent switches,${ }^{12}$ electroluminescent films, ${ }^{13,14}$ and photosensitizers in both solar cells and photodynamic therapy. ${ }^{15-17}$ However, the emission wavelength of the BODIPY core (generally $<600 \mathrm{~nm}$ ) is outside of the 650-1000 nm biological window, where auto-fluorescence and light scattering are minimized. ${ }^{18}$ Furthermore, conjugation of BODIPYs to large biomolecules is rather underdeveloped ${ }^{19,20}$ and relies on synthetic methodology involving extended reaction times and harsh conditions. A bathochromic shift of the emission wavelength has been achieved by extending the $\pi$-conjugation of the dipyrrinato ligand of BODIPYs (Figure 1). ${ }^{21}$ All eight positions of the dipyrrinato core can be substituted with groups such as aryl, ethynylphenyl, steryl and vinyl, as can the fluoro substituents at boron ${ }^{21-28}$ (Figure 1). Particularly appealing is the incorporation of an acetelyne substituent on the $\beta$-positions of the dipyrrinato ligand with the goal of both extending $\pi$ conjugation and introducing a functional handle for linkage to other moieties. ${ }^{29-43}$ Despite the large body of work concerning the synthesis and the reactions of alkene-substituted $F$-BODIPYs, systems substituted with terminal alkenes are scarce. ${ }^{44}$

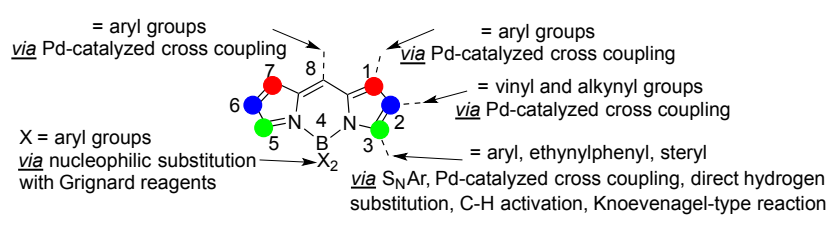

Figure 1. BODIPYs exhibiting a bathochromic shift through extension of the $\pi$-conjugation.

In an ongoing effort to synthesize new dipyrrole-based dyes and investigate their photochemical properties and reactivity, ${ }^{45-50}$ we targeted the meso- $H$ asymmetric dipyrrin 1 (Scheme 1), featuring a terminal alkyne directly conjugated to the dipyrrinato core, and complexed to $-\mathrm{BF}_{2}$ to provide the $F$-BODIPY 4. Furthermore, we report the generation and 
reactivity of the first bromovinyl- (5) and enol-substituted (6) F-BODIPYs (Scheme 2) bearing terminal alkenyl units. Our pre-functionalization synthetic approach to $\mathbf{1}$ (Scheme 1), ${ }^{3}$ involving condensation of the corresponding alkyne-substituted 2-formyl pyrrole (2) ${ }^{51}$ and krypto pyrrole (3), allows independent modification of the electronic and steric features of each pyrrole of the dipyrrin. Although F-BODIPYs have been isolated bearing alkynyl functionality at the $\beta$ position, most are symmetrical (with an alkynyl unit on each pyrrolic unit) and/or are synthesized in one pot from the requisite pyrroles, i.e. not isolated at the pre-ligand step. ${ }^{29,30,41,51-}$ ${ }^{55}$ Burgess reported the synthesis of an asymmetric F-BODIPY similar to 4 and bearing a terminal alkyne at the $\beta$-position of the dipyrrinato core, but the constituent dipyrrin was not isolated..$^{55}$

We first synthesized the asymmetric dipyrrin hydrobromide salt 9, bearing a TMSprotected alkynyl unit (Scheme 1). The $\beta$-iodo pyrrole $7^{55}$ underwent Sonogashira cross-coupling reaction conditions with TMS-acetylene to afford pyrrole $8 .{ }^{51}$ Condensation of $\mathbf{8}$ and the $\alpha$-free pyrrole 3 afforded the TMS-protected dipyrrin hydrobromide salt $\mathbf{9}$. However, upon treatment of 9 with $\mathrm{NEt}_{3}$ and $\mathrm{BF}_{3} \bullet \mathrm{OEt}_{2}$, loss of the TMS-group was accompanied by decomposition rather than formation of the corresponding F-BODIPY. At this point, we began to appreciate the unusual susceptibility of the $\beta$-alkynyl unit towards Lewis acid activation.

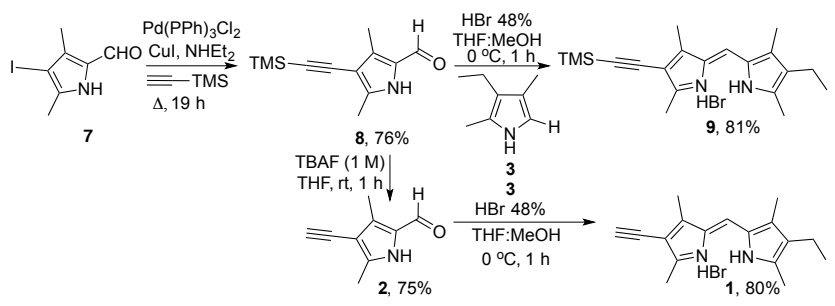

Scheme 1. Synthesis of dipyrrins bearing alkynyl groups. 
Fortunately, TMS-deprotection could be achieved earlier in the sequence using the pyrrole $\mathbf{8}$, followed by condensation of the resulting 2-formyl-4-alkynynl pyrrole $\mathbf{2}$ with $\mathbf{3}$ to provide the desired dipyrrin hydrobromide salt $\mathbf{1}$ (Scheme 1). The structure of $\mathbf{1}$, featuring a terminal alkyne directly conjugated to the dipyrrinato core, was confirmed using X-ray crystallography (see Supporting Information, Figure S1). The ability of the alkynyl unit to extend the $\pi$-conjugated system of the dipyrrinato core is demonstrated by the $\mathrm{C}(6)-\mathrm{C}(15)$ bond length of $1.438 \AA$, intermediate between the expected length of $\mathrm{C}-\mathrm{C}$ single and double bonds (Figure 2). In contrast, the structure of the dipyrrin hydrobromide salt 10 (Supporting Information, Figure S2), ${ }^{56}$ with only ethyl groups substituting the $\beta$-positions of the dipyrrinato core, features a $\mathrm{C}(2)-\mathrm{C}(11)$ bond length of $1.503 \AA$. The short $\mathrm{C}(6)-\mathrm{C}(15)$ bond length within 1 suggests that the triple bond $\pi$-system participates in the delocalization of electrons originating within the dipyrrinato core, and is thereby activated towards electrophilic attack.

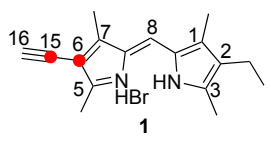

1.438

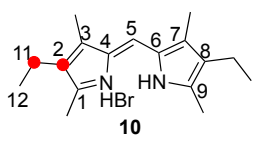

1.503

Figure 2. Comparison of bond length between dipyrrin hydrobromides $\mathbf{1}$ and $\mathbf{1 0}$.

Treatment of dipyrrin hydrobromide salt 1 with $\mathrm{NEt}_{3}$ and $\mathrm{BF}_{3} \bullet \mathrm{OEt}_{2}$ did not initially afford the expected $F$-BODIPY 4 (Scheme 2). Instead, two new stable compounds, that were inseparable via chromatography over silica, were isolated. The ${ }^{1} \mathrm{H}$ NMR spectrum (Supporting Information, Figure S3a) of the mixture contained two sets (4:1 ratio) of vinylic protons between 6.00 and $5.20 \mathrm{ppm}$. Although the ${ }^{11} \mathrm{~B}$ NMR triplet diagnostic was too broad to reveal detailed information beyond confirming the presence of $F$-BODIPYs, the ${ }^{19} \mathrm{~F}$ NMR spectrum clearly displayed two overlapping quartets, thereby also suggesting the presence of two $F$-BODIPYs in 
the mixture. ${ }^{1} \mathrm{H}-{ }^{13} \mathrm{C}$ HSQC NMR analysis showed distinct correlations between peaks due to each set of vinylic protons ( $\mathrm{A}$ and $\mathrm{B}$ in Figure 3 ) and signals due to their respective carbon atoms, implying that both compounds in the mixture feature a terminal vinyl group at the $\beta$ position.

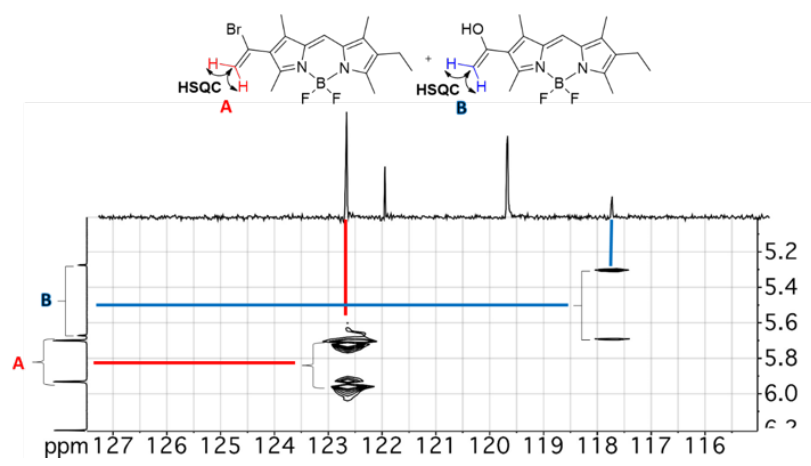

Figure 3. ${ }^{1} \mathrm{H}-{ }^{13} \mathrm{C}$ HSQC NMR spectra of the mixture of $F$-BODIPYs 5 and $\mathbf{6}$.

Alongside two-dimensional NMR analysis, mass spectrometric analysis of the mixture enabled the identification of these two products as the bromovinyl- and enol-containing $F$ BODIPYs 5 and 6, respectively, with the bromovinyl- derivative as the major constituent (Scheme 2). Both materials presumably formed as a result of addition across the triple bond, with 6 as a result of exposure to water in the work-up. To determine whether $\mathbf{5}$ was formed as the direct product of the reaction of 4 with $\mathrm{NEt}_{3}$ and $\mathrm{BF}_{3} \bullet \mathrm{OEt}_{2}$, or during work-up, the reaction was monitored through ${ }^{1} \mathrm{H}$ NMR spectroscopic analysis (Supplementary Information, Figures S3b and S3c). Analysis of the vinylic region revealed that the bromovinyl analog $\mathbf{5}$ dominates throughout the reaction, with signals due to $\mathbf{6}$ becoming more prominent upon addition of aqueous acid in work-up. Although the use of silica did not enable the chromatographic separation of $\mathbf{5}$ and $\mathbf{6}$, the use of basic alumina was effective in that it resulted in elimination of $\mathrm{HBr}$ from 5 to produce the desired F-BODIPY 1 (Scheme 2, yields based on the amount of 5 in the mixture). However, the remarkably stable enol F-BODIPY 6 was recovered. The mixture of 
5 and 6 was reacted with either $\mathrm{TsCl}$ or MeI in the presence of a base (DIPEA and $\mathrm{NEt}_{3}$, respectively). However, in both cases, only starting materials were recovered.

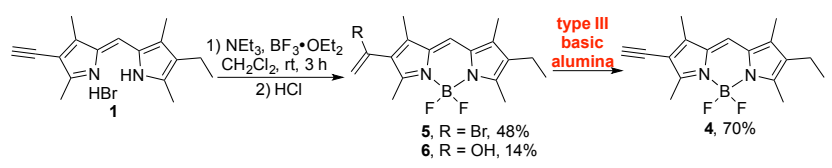

Scheme 2. Reaction of dipyrrin hydrobromide 1 with $\mathrm{BF}_{3} \bullet \mathrm{OEt}_{2}$ and $\mathrm{NEt}_{3}$.

The elimination of $\mathrm{HBr}$ from 5 to form the alkynyl-substituted $F$-BODIPY 4 was investigated spectroscopically via treatment of a solution of the mixture of 5 and $\mathbf{6}$ in $\mathrm{CD}_{3} \mathrm{CN}$ with $\mathrm{NEt}_{3}$ (Supporting Information, Figure S4). Two sets of vinyl peaks were clearly apparent until 1 equiv. of $\mathrm{NEt}_{3}$ was added whereupon the alkynyl peak at $3.60 \mathrm{ppm}$ of 4 appeared. Further additions of $\mathrm{NEt}_{3}$ resulted in increasing conversion to 4 at the expense of only the bromo-vinyl substituted $F$-BODIPY 5, as determined through monitoring the vinyl protons. The vinyl proton peaks of the enol-containing $F$-BODIPY 6 remained constant, matching the previous observation following chromatography over basic alumina. Presumably, the conversion of $\mathbf{5}$ to $\mathbf{4}$ does not occur in the original complexation reaction, despite the presence of excess $\mathrm{NEt}_{3}$, due to equilibria involving $\mathrm{NEt}_{3}$ preferably interacting with $\mathrm{HF}$ and $\mathrm{HBF}_{4}$, as well as forming the $\mathrm{BF}_{3} \bullet \mathrm{NEt}_{3}$ Lewis pair, ${ }^{45,57}$ which was reported unreactive towards terminal alkyne. ${ }^{58}$

Cognizant that activation of terminal alkynes can occur in the presence of Lewis acids, including those involving boron species, ${ }^{53,54,58-64}$ dipyrrin hydrobromide salt $\mathbf{1}$ was reacted with stoichiometric $\mathrm{BF}_{3} \bullet \mathrm{OEt}_{2}$ whereby formation of the $F$-BODIPY would not be expected. ${ }^{45} \mathrm{~A}$ solution of 1 in $\mathrm{CDCl}_{3}$ (Figure 4, spectrum a) was treated with $\mathrm{BF}_{3} \bullet \mathrm{OEt}_{2}$ (1 equiv.), under anhydrous conditions, and the mixture analyzed using ${ }^{1} \mathrm{H}$ NMR spectroscopy. Immediately after the addition, the intensity of the signal due to the alkynyl proton of $\mathbf{1}$ diminished and two sets of vinyl peaks appeared (Figure 4, spectrum b). One of the sets of signals due to vinyl protons 
corresponded to our previous characterization of 5 (Figure 4, spectrum g). The other set of vinylic peaks was assigned to the free-base 11. The broad peak in the range of 4.20 and $3.90 \mathrm{ppm}$ corresponds to the ethyl groups originating from $\mathrm{BF}_{3} \bullet \mathrm{OEt}_{2}$. Sequential ${ }^{1} \mathrm{H} \mathrm{NMR}$ analysis (Figure 4, spectra c-f), revealed conversion of $\mathbf{1}$ to the mixture of $\mathbf{5}$ and the corresponding free-base $\mathbf{1 1}$. Stoichiometric activation of the triple bond of the dipyrrin $\mathbf{1}$ clearly enables addition of $\mathrm{HBr}$ (from the original dipyrrin hydrobromide salt) across the exo-cyclic $\pi$-system. To the best of our knowledge, this is the first report whereby the HX unit of a dipyrrin salt reacts with the substituents about the dipyrrinato core. The same experiment was repeated using 1-hexyne in $\mathrm{CDCl}_{3}$ (Supporting Information, Figure S5), but ${ }^{1} \mathrm{H}$ NMR spectroscopy revealed no reaction over 3 hours thus confirming the surprising sensitivity of the terminal alkyne of dipyrrin hydrobromide $\mathbf{1}$. Treatment of the free-base of $\mathbf{1}$, prepared through washing the hydrobromide salt with $2 \mathrm{M} \mathrm{NaOH}$, with 1 equiv. $\mathrm{BF}_{3} \bullet \mathrm{OEt}_{2}$ resulted in the dark green solution producing a dark purple colour and then a black polymerized precipitate. Attempts to solubilize the precipitate in organic solvents, including DMSO- $d_{6}$, were unsuccessful. Similar polymerization occurred when the $F$-BODIPY 4 was treated with stoichiometric $\mathrm{BF}_{3} \bullet \mathrm{OEt}_{2}$. It is curious that the alkynyl functionality of the salt $\mathbf{1}$ is essentially protected upon reaction with $\mathrm{HBr}$, yet this unit of $\mathrm{HBr}$ was introduced with the intention of protecting the dipyrrinato unit. The $\mathrm{HBr}$ addition product 5 essentially masks the triple bond, yet can be ready converted to the alkyne 4 upon treatment with base. 


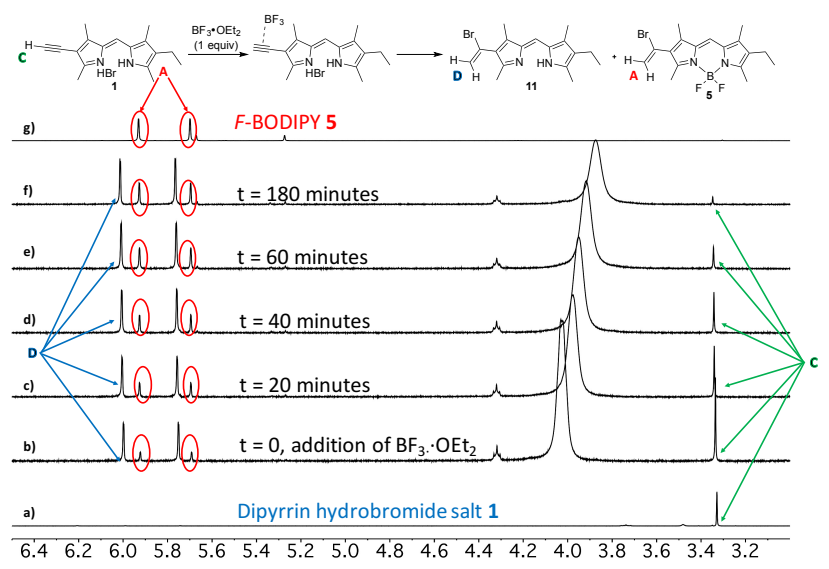

Figure 4. Treatment of a solution of dipyrrin 1 in $\mathrm{CDCl}_{3}(0.1 \mathrm{M})$ with 1 equiv. $\mathrm{BF}_{3} \bullet \mathrm{OEt}_{2}$.

The susceptibility of a conjugated alkynyl-substituted pyrrole to addition reactions was similarly observed when pyrrole $\mathbf{1 2}^{65}$ was subjected to Vilsmeier-Haack reaction conditions. Alongside the desired product 13, the alkynes 14 and 15 were isolated (note that initial formylation suffers from poor regioselectivity). Furthermore, the chlorovinyl-pyrrole $\mathbf{1 6}$ was also isolated, presumably as a consequence of $\mathrm{HCl}$ addition to the alkyne $\mathbf{1 4}$ under the reaction conditions (Scheme 3). The contribution of the pyrrolic nitrogen lone pair to the reactivity of substituents has been well-documented, ${ }^{66-69}$ and in the case of $\mathbf{4}$ and $\mathbf{1 5}$ is responsible for enabling a facile addition reaction across the triple bond.

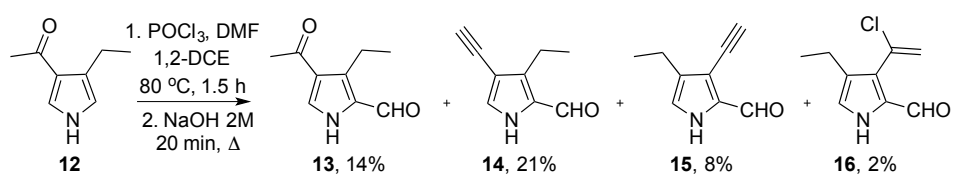

Scheme 3. Formylation of pyrrole 12 using Vilsmeier-Haack reaction conditions.

With the goal of extending the $\pi$-conjugation, the chemical reactivity of $F$-BODIPYs 4-6 was investigated. First, alkyne-containing F-BODIPY 4 was reacted with 3-iodoanisole under Sonogashira cross-coupling conditions (a, Scheme 4). ${ }^{55}$ The expected aryl-conjugated alkynyl $F$ BODIPY 17 was isolated in 72\% yield. Interestingly, reaction of the mixture of 5 and $\mathbf{6}(4: 1$ 
ratio) with 3-iodoanisole, under the same conditions also gave the aryl-conjugated alkynyl $F$ BODIPY 17 (53\% yield based on the amount of 5 in the mixture, reaction $b$ in Scheme 4). The enol 6 again remained unreacted, and was isolated in a mixture alongside the excess 3iodoanisole.

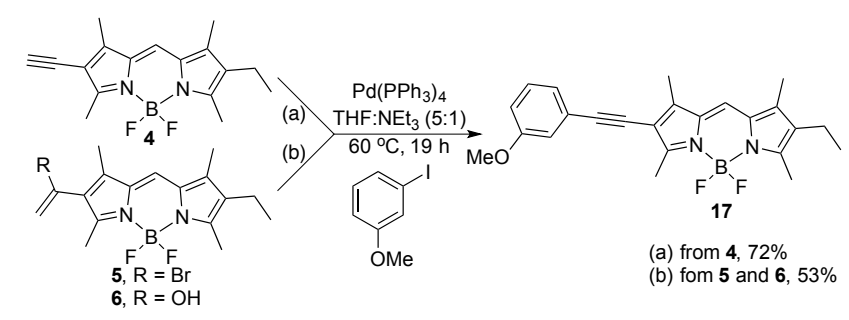

Scheme 4. Sonogashira cross-coupling reaction between F-BODIPYs 4-6 and 3-iodoanisole.

The absorbance and fluorescence exhibited by the new $F$-BODIPYs 4 and 17 were compared to those of the known F-BODIPY 18, formed from 10, with ethyl groups on each of the $\beta$-positions of the dipyrrinato core. The replacement of one of the $\beta$-ethyl groups of $\mathbf{1 8}$ with an alkynyl moiety (4), results in a negligible red-shift absorbance maximum of $3 \mathrm{~nm}$ whereas the extended conjugation seen in $\mathbf{1 7}$ results in a red-shift of $13 \mathrm{~nm}$ (Figure 5). Noteworthy is the fact that the emission wavelengths are significantly red-shifted courtesy of an increased Stoke's shift for both $4(14 \mathrm{~nm})$ and $17(29 \mathrm{~nm})$ cf. just $4 \mathrm{~nm}$ for the per-alkyl analog $\mathbf{1 8}$. However, the $F$ BODIPY 17 exhibits a slightly lower quantum yield $\left(\phi_{\text {fluo }}=0.60\right)$ compared to the simpler analogs (near quantitative, see Supporting Information).

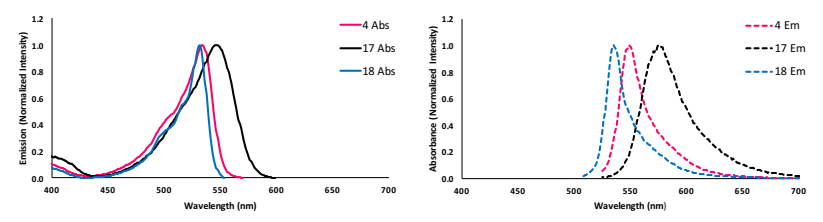

Figure 5. Absorbance and emission of $F$-BODIPYs 4, 17 and 18 
In conclusion, the synthesis, characterization and reactivity of the asymmetric meso- $H$ alkyne-conjugated dipyrrin 1 are reported. The reaction of 1 with $\mathrm{BF}_{3} \bullet \mathrm{OEt}_{2}$ and $\mathrm{NEt}_{3}$ revealed that the conjugated terminal alkynyl unit undergoes electrophilic attack. Future work involving dipyrrins bearing terminal alkynes should take this unusual reactivity into consideration. Two new terminal alkene-substituted $F$-BODIPYs, 5 and $\mathbf{6}$, were isolated after treating $\mathbf{1}$ with $\mathrm{BF}_{3} \bullet \mathrm{OEt}_{2}$ and $\mathrm{NEt}_{3} .{ }^{1} \mathrm{H}$ NMR spectroscopic analysis suggests activation of the alkynyl unit by $\mathrm{BF}_{3}$, and subsequent nucleophilic addition of $\mathrm{HBr}$ onto the triple bond. Basic conditions induced elimination of $\mathrm{HBr}$ from 5 and restoration of the conjugated triple bond. Extension of the $\pi$ conjugation of $\mathbf{4}$ and $\mathbf{5}$ give the new dye 17. The absorption and emission spectra of $F$-BODIPYs 4 and 17 were compared to a per alkyl dipyrrin, thereby enabling the effect of the terminal and substituted alkynyl units to be assessed. The extension of the $\pi$-conjugation resulted in red shifted absorbance and a Stoke's shift of almost $30 \mathrm{~nm}$.

\section{Experimental procedures}

All chemicals were purchased and used as received unless otherwise indicated. Moisture sensitive reactions were performed in oven-dried glassware and under a positive pressure of nitrogen. Air- and moisture-sensitive compounds were introduced via syringe or cannula through a rubber septum. Flash chromatography was performed using either ultra-pure silica (230-400 $\mathrm{mm}$ ) or 150 mesh Brockmann III activated basic alumina oxide as indicated. The NMR spectra were recorded using a $500 \mathrm{MHz}$ spectrometer instrument using $\mathrm{CDCl}_{3}$ as solvent and is reported in parts per million (ppm). Internal solvent was referenced at $7.26 \mathrm{ppm}$ for ${ }^{1} \mathrm{H}$ and at $77.16 \mathrm{ppm}$ for ${ }^{13} \mathrm{C}$ when using $\mathrm{CDCl}_{3}$. All chemical shifts regarding ${ }^{11} \mathrm{~B}$ and ${ }^{19} \mathrm{~F}$ were referenced using the absolute referencing procedure standard on digital spectrometers. For ${ }^{11} \mathrm{~B}$ chemical shifts the 0 ppm position corresponds to the chemical shift of $\mathrm{BF}_{3} \cdot \mathrm{Et}_{2} \mathrm{O}\left(15 \%\right.$ in $\left.\mathrm{CDCl}_{3}\right)$ whereas for ${ }^{19} \mathrm{~F}$ the 
reference compound is $\mathrm{CCl}_{3} \mathrm{~F}$. Coupling constants $(J)$ are given in Hertz $(\mathrm{Hz})$. Mass spectra were obtained using TOF and LCQ Duo ion trap instruments operating in $\mathrm{ESI}^{+/-}$or APCI mode, as indicated. Compounds $2,{ }^{51} \mathbf{3},{ }^{55} \mathbf{8},{ }^{51} \mathbf{1 0},{ }^{70} \mathbf{1 2}^{65}$ and $\mathbf{1 8}^{71}$ were prepared according to literature procedures.

\section{General Procedure for Absorbance and Emission Measurements}

A $10 \mathrm{~mm}$ quartz cuvette was used. For fluorescence experiments, a slit width of $3 \mathrm{~nm}$ was used for both excitation and emission. Each compound was dissolved in $\mathrm{CH}_{2} \mathrm{Cl}_{2}$.

\section{Fluorescence Quantum Yield}

Relative fluorescence quantum yields were obtained by comparing the area under the emission spectrum of the compound of interest to that of the standard, rhodamine $6 \mathrm{G}$ ( $\phi=0.94$ in ethanol). ${ }^{72}$ The excitation wavelength was $520 \mathrm{~nm}$ for rhodamine $6 \mathrm{G}, F$-BODIPY 4 and $F$ BODIPY 17. The excitation wavelength was $500 \mathrm{~nm}$ for the reference compound $\mathbf{1 8}$, and compared to rhodamine $6 \mathrm{G}$ excited at $500 \mathrm{~nm}$. Relative quantum yields were determined using Equation $1,{ }^{73}$ where $\Phi_{\text {st }}$ is the reported quantum yield of the standard, I is the area of the integrated emission spectra, $\mathrm{A}$ is the absorbance at the excitation wavelength and $\eta$ is the refractive index of the solvent used. The subscripts "X" and "st" denote the unknown and standard compound, respectively.

$$
\Phi_{X}=\Phi_{s t}\left(\frac{I_{X}}{I_{s t}}\right)\left(\frac{A_{s t}}{A_{X}}\right)\left(\frac{\eta_{X}^{2}}{\eta_{s t}^{2}}\right)
$$

Equation 1. Relative quantum yield $\left(\Phi_{\mathrm{X}}\right)$.

\section{3-Ethyl-5-((4-ethynyl-3,5-dimethyl-2H-pyrrol-2-ylidene)methyl)-2,4-dimethyl-1 $H$-pyrrole hydrobromide (1)}


2-Formyl pyrrole $\mathbf{2}^{51}(0.10 \mathrm{~g}, 0.680 \mathrm{mmol})$ was dissolved in MeOH:THF (1:1.5 $\left.\mathrm{mL}\right)$ and $\alpha$-free pyrrole $3^{55}(0.08 \mathrm{~g}, 0.680 \mathrm{mmol})$ was added in one portion at room temperature. The reaction mixture was degassed $(\times 3)$ and $48 \%$ aq. $\mathrm{HBr}(0.18 \mathrm{~mL}, 0.680 \mathrm{mmol})$ was added at $0{ }^{\circ} \mathrm{C}$. The reaction mixture was placed under an atmosphere of $\mathrm{N}_{2}$ and stirred for 1 hour and then poured into $\mathrm{Et}_{2} \mathrm{O}(30 \mathrm{~mL})$. The resulting precipitate was isolated via suction filtration and then washed with $\mathrm{Et}_{2} \mathrm{O}(10 \mathrm{~mL} \times 3)$ to afford the title compound as a bright red solid (80\%). M.p.: decomposition $>170{ }^{\circ} \mathrm{C} .{ }^{1} \mathrm{H} \mathrm{NMR}\left(\mathrm{CDCl}_{3}, 500 \mathrm{MHz}\right) 1.08(\mathrm{t}, J=7.6 \mathrm{~Hz}, 3 \mathrm{H}), 2.29(\mathrm{~s}, 3 \mathrm{H}), 2.39$ (s, 3H), $2.44(\mathrm{q}, J=7.6 \mathrm{~Hz}, 2 \mathrm{H}), 2.70(\mathrm{~s}, 3 \mathrm{H}), 2.71(\mathrm{~s}, 3 \mathrm{H}), 3.33(\mathrm{~s}, 1 \mathrm{H}), 7.07(\mathrm{~s}, 1 \mathrm{H}), 13.16(\mathrm{br}$ s, 1H), 13.29 (br s, 1H) ppm. ${ }^{13} \mathrm{C}$ NMR $\left(\mathrm{CDCl}_{3}, 125 \mathrm{MHz}\right)$ 10.2, 11.4, 13.2, 13.4, 14.4, 17.4, 75.2, 83.8, 110.9, 119.8, 124.8, 127.8, 132.4, 143.6, 145.5, 155.3, 158.5 ppm. HRMS-ESI (m/z): $[\mathrm{M}-\mathrm{Br}]^{+}$calcd for $\mathrm{C}_{17} \mathrm{H}_{21} \mathrm{~N}_{2}, 253.1699$; found, 253.1693.

3-Ethyl-5-((4-ethynyl-3,5-dimethyl-2H-pyrrol-2-ylidene)methyl)-2,4-dimethyl-1H-pyrrole (free-base)

A solution of dipyrrin $1(0.10 \mathrm{~g}, 0.300 \mathrm{mmol})$ in $\mathrm{CH}_{2} \mathrm{Cl}_{2}(10 \mathrm{~mL})$ was washed with $2 \mathrm{M} \mathrm{NaOH}$ $(10 \mathrm{~mL} \times 3)$. The organic layer was washed with water $(10 \mathrm{~mL} \times 2)$ and brine $(10 \mathrm{~mL})$, dried over $\mathrm{Na}_{2} \mathrm{SO}_{4}$ and concentrated under reduced pressure to give the title compound as a dark green solid (0.07 g, quant.). M.p.: decomposition $>110{ }^{\circ} \mathrm{C} .{ }^{1} \mathrm{H} \mathrm{NMR}\left(\mathrm{CDCl}_{3}, 500 \mathrm{MHz}\right) 1.06$ (t, $J=7.6$ Hz, 3H), 2.13 (s, 3H), 2.27 (s, 3H), 2.31 (s, 3H), 2.37 (q, J= $7.6 \mathrm{~Hz}, 2 \mathrm{H}), 2.40$ (s, 3H), 3.30 (s, 1H), $6.66(\mathrm{~s}, 1 \mathrm{H}), 8.84$ (br s, $1 \mathrm{H}) \mathrm{ppm} .{ }^{13} \mathrm{C} \mathrm{NMR}\left(\mathrm{CDCl}_{3}, 125 \mathrm{MHz}\right)$ 9.6, 10.7, 14.6, 14.8, 15.2, 17.9, 78.5, 81.9, 109.3, 116.3, 132.6, 134.2, 136.1, 138.1, 140.0, 151.1, 157.3 ppm. HRMS-ESI (m/z): $[\mathrm{M}+\mathrm{H}]^{+}$calcd for $\mathrm{C}_{17} \mathrm{H}_{21} \mathrm{~N}_{2}, 253.1699$; found, 253.1707 . 
$\mathrm{NEt}_{3}(2.5 \mathrm{~mL}, 18.0 \mathrm{mmol})$ was added to a solution of dipyrrin hydrobromide 1 (1.00 g, 3.00 mmol) in anhydrous $\mathrm{CH}_{2} \mathrm{Cl}_{2}(313 \mathrm{~mL})$ at room temperature under a $\mathrm{N}_{2}$ atmosphere. The reaction mixture was stirred for 15 minutes and $\mathrm{BF}_{3} \bullet \mathrm{OEt}_{2}(3.3 \mathrm{~mL}, 27.0 \mathrm{mmol})$ was then added. After 2 hours, $\mathrm{NEt}_{3}(2.5 \mathrm{~mL}, 18.0 \mathrm{mmol})$ and $\mathrm{BF}_{3} \bullet \mathrm{OEt}_{2}(3.3 \mathrm{~mL}, 27.0 \mathrm{mmol})$ were added and the reaction mixture stirred for an additional 2 hours. $5 \mathrm{M} \mathrm{HCl}(20 \mathrm{~mL})$ was added and the two layers were separated. The organic layer was washed with $5 \mathrm{M} \mathrm{HCl}(20 \mathrm{~mL} \times 4)$, water $(50 \mathrm{~mL} \times$ 2) and brine $(50 \mathrm{~mL})$, dried over $\mathrm{Na}_{2} \mathrm{SO}_{4}$ and concentrated under reduced pressure. The crude mixture was purified using column chromatography over either $\mathrm{SiO}_{2}$ or type III neutral $\mathrm{Al}_{2} \mathrm{O}_{2}$ (hexanes:EtOAc, 100:0, 95:5) and an inseparable mixture of compounds $\mathbf{5}$ and $\mathbf{6}$ was obtained as a bright purple powder $(0.68 \mathrm{~g})$. Purification of this mixture over type III basic $\mathrm{Al}_{2} \mathrm{O}_{2}$ (hexanes:EtOAc, 100:0, 99:1, 98:2, 95:5, 90:10) gave 4 as a dark red solid (70\%). Data for $\mathbf{4}$ : m.p.: decomposition> $150{ }^{\circ} \mathrm{C} .{ }^{1} \mathrm{H}$ NMR $\left(\mathrm{CDCl}_{3}, 500 \mathrm{MHz}\right) 1.08(\mathrm{t}, J=7.6 \mathrm{~Hz}, 3 \mathrm{H}), 2.19(\mathrm{~s}, 3 \mathrm{H})$, $2.29(\mathrm{~s}, 3 \mathrm{H}), 2.40(\mathrm{q}, J=7.6 \mathrm{~Hz}, 2 \mathrm{H}), 2.53(\mathrm{~s}, 3 \mathrm{H}), 2.59$ (s, 3H), $3.30(\mathrm{~s}, 1 \mathrm{H}), 7.01(\mathrm{~s}, 1 \mathrm{H}) \mathrm{ppm}$; ${ }^{13} \mathrm{C}$ NMR $\left(\mathrm{CDCl}_{3}, 125 \mathrm{MHz}\right) 9.5,10.6,13.1,13.3,14.4,17.4,76.8,82.8,111.5,119.8,130.7$, 133.8, 134.6, 139.3, 140.6, 156.3, $159.7 \mathrm{ppm} ;{ }^{11} \mathrm{~B}\{1 \mathrm{H}\} \mathrm{NMR}\left(\mathrm{CDCl}_{3}, 160 \mathrm{MHz}\right) 0.74(\mathrm{t}, J=31$ $\mathrm{Hz}) \mathrm{ppm} ;{ }^{19} \mathrm{~F}$ NMR $\left(\mathrm{CDCl}_{3}, 470 \mathrm{MHz}\right)-146.5(\mathrm{q}, J=31 \mathrm{~Hz})$; HRMS-ESI $(\mathrm{m} / \mathrm{z}):[\mathrm{M}+\mathrm{Na}]^{+}$calcd for $\mathrm{C}_{17} \mathrm{H}_{19} \mathrm{BF}_{2} \mathrm{~N}_{2} \mathrm{Na}$, 323.1502; found, 323.1492; UV/vis $\left(\mathrm{CH}_{2} \mathrm{Cl}_{2}\right): 534 \mathrm{~nm}\left(\varepsilon=100280 \mathrm{~L} \mathrm{~mol}^{-1}\right.$ $\left.\mathrm{cm}^{-1}\right)$; Data for the mixture of 5 and 6, present in a 4:1 ratio: ${ }^{1} \mathrm{H} \mathrm{NMR}\left(\mathrm{CDCl}_{3}, 500 \mathrm{MHz}\right) 1.08(\mathrm{t}$, $J=7.6 \mathrm{~Hz},(0.8 \times 3 \mathrm{H})+(0.2 \times 3 \mathrm{H}), \mathrm{CH}_{3} \mathrm{CH}_{2}$ of 5 and 6), $2.19\left(\mathrm{~s},(0.8 \times 3 \mathrm{H})+(0.2 \times 3 \mathrm{H}), \mathrm{CH}_{3}\right.$ of 5 and 6), $2.25\left(\mathrm{~s}, 0.8 \times 3 \mathrm{H}, \mathrm{CH}_{3}\right.$ of 5), $2.27\left(\mathrm{~s}, 0.8 \times 3 \mathrm{H}, \mathrm{CH}_{3}\right.$ of $\left.\mathbf{6}\right), 2.40(\mathrm{q}, J=7.6 \mathrm{~Hz},(0.8 \times$ $2 \mathrm{H})+(0.2 \times 2 \mathrm{H}), \mathrm{CH}_{3} \mathrm{CH}_{2}$ of 5 and 6), $2.53\left(\mathrm{~s},(0.8 \times 3 \mathrm{H})+(0.2 \times 3 \mathrm{H}), \mathrm{CH}_{3}\right.$ of 5 and $\left.\mathbf{6}\right), 2.55(\mathrm{~s}$, $0.8 \times 3 \mathrm{H}, \mathrm{CH}_{3}$ of 5), $2.56\left(\mathrm{~s}, 0.2 \times 3 \mathrm{H}, \mathrm{CH}_{3}\right.$ of 6$) 5.27\left(\mathrm{~s}, 0.2 \times 1 \mathrm{H}, \mathrm{CH}_{2} \mathrm{COH}\right.$ of 6$), 5.67(\mathrm{~s}, 0.2 \times$ $1 \mathrm{H}, \mathrm{CH}_{2} \mathrm{COH}$ of 6), $5.70\left(\mathrm{~s}, 0.8 \times 1 \mathrm{H}, \mathrm{CH}_{2} \mathrm{CBr}\right.$ of 5), $5.93\left(\mathrm{~s}, 0.8 \times 1 \mathrm{H}, \mathrm{CH}_{2} \mathrm{CBr}\right.$ of 5), $7.02(\mathrm{~s}$, 
$0.8 \times 1 \mathrm{H}$, meso- $H$ of $\mathbf{5}), 7.03(\mathrm{~s}, 0.2 \times 1 \mathrm{H}$, meso- $H$ of $\mathbf{6}) \mathrm{ppm} ;{ }^{13} \mathrm{C} \mathrm{NMR}\left(\mathrm{CDCl}_{3}, 125 \mathrm{MHz}\right) 9.6$, $10.3(\times 2), 13.1(\times 2), 14.5,17.4,117.9,120.0,122.2,122.9,129.5,131.0,132.9,133.7,134.4$ 136.2, 138.9, 151.9, 159.4 ppm; ${ }^{11} \mathrm{~B}\{1 \mathrm{H}\}$ NMR $\left(\mathrm{CDCl}_{3}, 160 \mathrm{MHz}\right) 0.83(\mathrm{t}, J=31 \mathrm{~Hz}) \mathrm{ppm} ;{ }^{19} \mathrm{~F}$ NMR $\left(\mathrm{CDCl}_{3}, 470 \mathrm{MHz}\right)-146.1$ (two overlapping q, $J=33 \mathrm{~Hz}$ ); HRMS-APCI $(\mathrm{m} / \mathrm{z}): 5[\mathrm{M}]^{+}$ calcd for $\mathrm{C}_{17} \mathrm{H}_{21} \mathrm{BBrF}_{2} \mathrm{~N}_{2}, 381.0944$; found, 381.0948) and $\mathbf{6}[\mathrm{M}+\mathrm{H}]^{+}$calcd for $\mathrm{C}_{17} \mathrm{H}_{22} \mathrm{BF}_{2} \mathrm{~N}_{2} \mathrm{O}$, 319.1788; found, 319.1779).

2-((3,5-Dimethyl-4-((trimethylsilyl)ethynyl)-2H-pyrrol-2-ylidene)methyl)-4-ethyl-3,5dimethyl-1 $H$-pyrrole hydrobromide (9)

2-Formyl pyrrole $\mathbf{8}^{51}$ (0.30 g, $\left.1.37 \mathrm{mmol}\right)$ was dissolved in MeOH:THF (1:1, $\left.10 \mathrm{~mL}\right)$, and $\alpha$-free pyrrole $3^{55}(0.20 \mathrm{~g}, 1.64 \mathrm{mmol})$ was added in one portion at room temperature. The reaction mixture was degassed $(\times 3)$ and $48 \%$ aq. $\mathrm{HBr}(0.75 \mathrm{~mL}, 1.37 \mathrm{mmol})$ was added at $0{ }^{\circ} \mathrm{C}$. The reaction mixture was placed under an atmosphere of $\mathrm{N}_{2}$ and stirred for 1.5 hours and then poured into $\mathrm{Et}_{2} \mathrm{O}(50 \mathrm{~mL})$. The resulting precipitate was isolated via suction filtration and then washed with $\mathrm{Et}_{2} \mathrm{O}(\times 3)$ to afford compound $\mathbf{1 3}$ as an orange solid (81\%). M.p.: decomposition $>220{ }^{\circ} \mathrm{C}$. ${ }^{1} \mathrm{H} \mathrm{NMR}\left(\mathrm{CDCl}_{3}, 500 \mathrm{MHz}\right) 0.26$ (s, 9H), 1.07 (t, $\left.J=7.6 \mathrm{~Hz}, 3 \mathrm{H}\right), 2.29$ (s, 3H), 2.38 (s, 3H), 2.43 (q, $J=7.6 \mathrm{~Hz}, 2 \mathrm{H}), 2.69$ (s, 6H), 7.05 (s, 1H), 13.12 (br s, 1H), 13.22 (br s, 1H) ppm. ${ }^{13} \mathrm{C}$ NMR $\left(\mathrm{CDCl}_{3}, 125 \mathrm{MHz}\right)$ 0.22, 10.2, 11.4, 13.2, 13.4, 14.4, 17.4, 96.1, 101.7, 112.3, 119.7, 124.9, 127.6, 132.2, 143.3, 145.2, 155.5, $158.0 \mathrm{ppm}$. HRMS-ESI (m/z): $[\mathrm{M}-\mathrm{Br}]^{+}$calcd for $\mathrm{C}_{20} \mathrm{H}_{29} \mathrm{~N}_{2} \mathrm{Si}$, 325.2095; found, 325.2096.

\section{4-Acetyl-3-ethyl-1 $H$-pyrrole-2-carbaldehyde (13)}

$\mathrm{POCl}_{3}(2.04 \mathrm{~mL}, 21.9 \mathrm{mmol})$ was added dropwise to DMF $(16 \mathrm{~mL})$ at $0{ }^{\circ} \mathrm{C}$ and under a $\mathrm{N}_{2}$ atmosphere. The mixture was allowed to warm to room temperature and then stirred for 15 minutes. A solution of pyrrole $\mathbf{1 2}^{65}(2.00 \mathrm{~g}, 14.6 \mathrm{mmol})$ in 1,2-DCE $(49 \mathrm{~mL})$ was added at $0{ }^{\circ} \mathrm{C}$ 
under inert atmosphere. The resulting mixture was heated to $80{ }^{\circ} \mathrm{C}$ and stirred for an additional 80 minutes. Aq. $\mathrm{NaOH}(2 \mathrm{M})$ was added to the reaction mixture until $\mathrm{pH}>8$, and the resulting emulsion was then heated at reflux temperature for 20 minutes. After cooling to room temperature, $\mathrm{H}_{2} \mathrm{O}(50 \mathrm{~mL})$ was added and the reaction mixture was extracted with EtOAc (50 $\mathrm{mL} \times 3)$. The combined organic layers were washed with brine $(50 \mathrm{~mL})$, dried over $\mathrm{Na}_{2} \mathrm{SO}_{4}$ and concentrated under reduced pressure. The crude mixture was purified using column chromatography on $\mathrm{SiO}_{2}$ (hexanes:EtOAc 80:20, 70:30) to afford the title compound as a brown solid (0.33 g, 14\%), along with 2-fomyl pyrroles 14 (0.44, 21\%), 15 (0.22 g, 10\%) and $16(0.05$ g, 2\%). The position of the formyl group was determined using 2D NMR (HSQC and HMBC). Data for 13: M.p.: $119-123{ }^{\circ} \mathrm{C} ;{ }^{1} \mathrm{H}$ NMR $\left(500 \mathrm{MHz} ; \mathrm{CDCl}_{3}\right) 1.26(\mathrm{t}, J=7.5 \mathrm{~Hz}, 3 \mathrm{H}), 2.44(\mathrm{~s}$, $3 \mathrm{H}), 3.11(\mathrm{q}, J=7.5 \mathrm{~Hz}, 2 \mathrm{H}), 7.61(\mathrm{~d}, J=3.4 \mathrm{~Hz}, 1 \mathrm{H}), 9.74(\mathrm{~s}, 1 \mathrm{H}), 10.03(\mathrm{br} \mathrm{s}, 1 \mathrm{H}) \mathrm{ppm} ;{ }^{13} \mathrm{C}$ NMR (125 MHz; $\left.\mathrm{CDCl}_{3}\right)$ 16.7, 17.9, 28.5, 125.0, 130.4, 130.7, 140.4, 179.1, 193.5 ppm; HRMSESI $(m / z):[\mathrm{M}+\mathrm{Na}]^{+}$calcd for $\mathrm{C}_{9} \mathrm{H}_{11} \mathrm{NNaO}_{2}, 188.0682$; found, 188.0680. 3-Ethyl-4-ethynyl-1Hpyrrole-2-carbaldehyde (14): M.p.: decomposition $>80{ }^{\circ} \mathrm{C}$, followed by melting at $119-120^{\circ} \mathrm{C}$. ${ }^{1} \mathrm{H} \mathrm{NMR}\left(\mathrm{CDCl}_{3}, 500 \mathrm{MHz}\right) 1.30(\mathrm{t}, J=7.6 \mathrm{~Hz}, 3 \mathrm{H}), 2.85$ (q, $\left.J=7.6 \mathrm{~Hz}, 2 \mathrm{H}\right), 3.10(\mathrm{~s}, 1 \mathrm{H}), 7.22$ (d, $J=3.0 \mathrm{~Hz}, 1 \mathrm{H}), 9.46$ (br s, 1H), 9.64 (s, 1H) ppm. ${ }^{13} \mathrm{C} \mathrm{NMR}\left(\mathrm{CDCl}_{3}, 125 \mathrm{MHz}\right)$ 16.4, 18.0, 76.3, 79.6, 106.8, 128.6, 129.6, 141.6, $177.9 \mathrm{ppm}$. HRMS-ESI $(\mathrm{m} / \mathrm{z}):[\mathrm{M}+\mathrm{Na}]^{+}$calcd for $\mathrm{C}_{9} \mathrm{H}_{9} \mathrm{NNaO}_{1}, 170.0576$; found, 170.0575. 4-Ethyl-3-ethynyl-1 $\mathrm{H}$-pyrrole-2-carbaldehyde (15): M.p.: decomposition $>95{ }^{\circ} \mathrm{C}$, followed by melting at $104-105{ }^{\circ} \mathrm{C} .{ }^{1} \mathrm{H}$ NMR $\left(\mathrm{CDCl}_{3}, 500 \mathrm{MHz}\right)$ 1.23 (t, 3H, $J=7.6 \mathrm{~Hz}$ ), 2.58 (q, 2H, $J=7.6 \mathrm{~Hz}$ ), 3.35 (s, 1H), 6.86 (br s, 1H), 9.28 (br s, $1 \mathrm{H}$ ), $9.68(\mathrm{~s}, 1 \mathrm{H}) \mathrm{ppm} .{ }^{13} \mathrm{C} \mathrm{NMR}\left(\mathrm{CDCl}_{3}, 125 \mathrm{MHz}\right) 14.5,18.8,75.2,83.8,114.7,123.3,132.5$, 134.2, 178.5 ppm. HRMS-ESI $(\mathrm{m} / \mathrm{z})$ : $[\mathrm{M}+\mathrm{Na}]^{+}$calcd for $\mathrm{C}_{9} \mathrm{H}_{9} \mathrm{NNaO}_{1}, 170.0576$; found, 170.0578. 3-(1-Chlorovinyl)-4-ethyl-1 H-pyrrole-2-carbaldehyde (16): M.p.: $65-66^{\circ} \mathrm{C} .{ }^{1} \mathrm{H}$ 
$\operatorname{NMR}\left(\mathrm{CDCl}_{3}, 500 \mathrm{MHz}\right) 1.22(\mathrm{t}, J=7.6 \mathrm{~Hz}, 3 \mathrm{H}), 2.59$ (q, $\left.J=7.6 \mathrm{~Hz}, 2 \mathrm{H}\right), 5.45(\mathrm{~d}, J=0.6 \mathrm{~Hz}$, $1 \mathrm{H}), 5.74(\mathrm{~d}, J=0.6 \mathrm{~Hz}, 1 \mathrm{H}), 6.87(\mathrm{~s}, 1 \mathrm{H}), 9.56(\mathrm{br} \mathrm{s}, 1 \mathrm{H}), 9.66(\mathrm{~s}, 1 \mathrm{H}) \mathrm{ppm} .{ }^{13} \mathrm{C} \mathrm{NMR}\left(\mathrm{CDCl}_{3}\right.$, $125 \mathrm{MHz})$ 14.6, 18.6, 119.2, 123.1, 128.2, 129.7, 131.1, 131.3, 179.2 ppm. HRMS-ESI $(\mathrm{m} / \mathrm{z})$ : $[\mathrm{M}+\mathrm{Na}]^{+}$calcd for $\mathrm{C}_{9} \mathrm{H}_{10} \mathrm{ClNNaO}, 206.0343$; found, 206.0341 .

\section{4,4-Difluoro-1,3,5,7-tetramethyl-2-(3-methoxyphenyl)ethynyl)-6-ethyl-8H-4-bora-3a,4a- diaza-s-indacene (17)}

A solution of 4 (56 mg, $0.187 \mathrm{mmol})$, 3-iodoanisole ( $27 \mu \mathrm{L}, 0.224 \mathrm{mmol})$ and CuI (7.0 mg, 0.037 mmol) in THF:NEt $3(5: 1,3.4 \mathrm{~mL})$ was degassed $(\times 3)$ and placed under a $\mathrm{N}_{2}$ atmosphere. $\mathrm{Pd}\left(\mathrm{PPh}_{3}\right)_{4}(22 \mathrm{mg}, 0.019 \mathrm{mmol})$ was added to the solution and the resulting reaction mixture degassed $(\times 2)$, placed under a positive pressure of $\mathrm{N}_{2}$ and stirred at $60{ }^{\circ} \mathrm{C}$ in a sealed system for 19 hours. The reaction mixture was diluted with EtOAc $(5.0 \mathrm{~mL})$, washed with water $(10 \mathrm{~mL} \times$ 3) and brine $(10 \mathrm{~mL})$, dried over $\mathrm{Na}_{2} \mathrm{SO}_{4}$, concentrated under reduced pressure and purified using column chromatography $\left(\mathrm{SiO}_{2}\right.$, hexanes:EtOAc, 80:20) to give the title compound as a dark pink solid (41\%). Following the above procedure compound 17 was also obtained (56 mg, 53\%) from the mixture of 5 and $6(100 \mathrm{mg})$. M.p.: $192-193{ }^{\circ} \mathrm{C} .{ }^{1} \mathrm{H}$ NMR $\left(\mathrm{CDCl}_{3}, 500 \mathrm{MHz}\right) 1.08$ (t, $J=7.6$ Hz, 3H), 2.20 (s, 3H), 2.35 (s, 3H), 2.41 (q, $J=7.6 \mathrm{~Hz}, 2 \mathrm{H}), 2.54$ (s, 3H), 2.65 (s, 3H), 3.83 (s, $3 \mathrm{H}), 6.88(\mathrm{ddd}, J=8.3,2.6,1.0 \mathrm{~Hz}, 1 \mathrm{H}), 7.02(\mathrm{~s}, 1 \mathrm{H}), 7.10(\mathrm{dt}, J=8.3,1.0 \mathrm{~Hz}, 1 \mathrm{H}), 7.24$ (t, $J=$ $8.3 \mathrm{~Hz}, 2 \mathrm{H}) \mathrm{ppm} .{ }^{13} \mathrm{C} \mathrm{NMR}\left(\mathrm{CDCl}_{3}, 125 \mathrm{MHz}\right) 9.6,10.8,13.1,13.6,14.5,17.4,55.5,82.1,95.3$, $112.8,114.6,116.3,119.7,124.1,124.9,129.5,131.2,133.7,134.4,139.0,139.8,156.4,159.2$ 159.4 ppm. ${ }^{11} \mathrm{~B}\{1 \mathrm{H}\} \mathrm{NMR}\left(\mathrm{CDCl}_{3}, 160 \mathrm{MHz}\right) 0.76(\mathrm{t}, J=31 \mathrm{~Hz}) \mathrm{ppm} .{ }^{19} \mathrm{~F}$ NMR $\left(\mathrm{CDCl}_{3}, 470\right.$ MHz) $-146.5(\mathrm{q}, J=31 \mathrm{~Hz})$. HRMS-ESI $(\mathrm{m} / \mathrm{z}):[\mathrm{M}+\mathrm{Na}]^{+}$calcd for $\mathrm{C}_{24} \mathrm{H}_{25} \mathrm{BF}_{2} \mathrm{~N}_{2} \mathrm{NaO}, 429.1920$; found, 429.1918. UV/vis $\left(\mathrm{CH}_{2} \mathrm{Cl}_{2}\right): 547 \mathrm{~nm}\left(\varepsilon=141000 \mathrm{~L} \mathrm{~mol}^{-1} \mathrm{~cm}^{-1}\right)$. 


\section{ASSOCIATED CONTENT}

\section{Supporting Information}

The Supporting Information is available free of charge on the ACS Publications website at DOI: XXX. X-ray structure and data for 1 and 10. NMR spectroscopic analysis of reactions. Absorption and emission data for 4, 17 and 18. NMR spectra of all new compounds.

\section{AUTHOR INFORMATION}

\section{Corresponding Author}

*E-mail: Alison.Thompson@dal.ca

\section{ORCID}

Alison Thompson: 0000-0003-4231-3446

\section{Notes}

The authors declare no competing financial interest.

\section{Acknowledgements}

This work was supported by the Natural Sciences and Engineering Research Council of Canada (NSERC). A.T. is Faculty of Science Killam Professor at Dalhousie University.

\section{References}

(1) Treibs, A.; Kreuzer, F. H. Liebigs Ann. Chem. 1968, 718, 208.

(2) Boens, N.; Leen, V.; Dehaen, W. Chem. Soc. Rev. 2012, 41, 1130. 
Boens, N.; Verbelen, B.; Dehaen, W. Eur. J. Org. Chem 2015, 6577.

(4) Loudet, A.; Burgess, K. Chem. Rev. 2007, 107, 4891.

(5) Ulrich, G.; Ziessel, R.; Harriman, A. Angew. Chem. Int. Ed. 2008, 47, 1184.

(6) Lakshmi, V.; Rajeswara Rao, M.; Ravikanth, M. Org. Biomol. Chem. 2015, 13, 2501.

(7) Ziessel, R.; Ulrich, G.; Harriman, A. New. J. Chem. 2007, 31, 496.

(8) Sarder, P.; Maji, D.; Achilefu, S. Bioconjugate Chem. 2015, 26, 963.

(9) Yuan, L.; Lin, W.; Zheng, K.; He, L.; Huang, W. Chem. Soc. Rev. 2013, 42, 622.

(10) Matsumoto, T.; Urano, Y.; Shoda, T.; Kojima, H.; Nagano, T. Org. Lett. 2007, 9, 3375.

(11) McCusker, C.; Carroll, J. B.; Rotello, V. M. Chem. Commun. 2005, 996.

(12) Rurack, K.; Kollmannsberger, M.; Daub, J. Angew. Chem. Int. Ed. 2001, 40, 385.

(13) Benstead, M.; Mehl, G. H.; Boyle, R. W. Tetrahedron 2011, 673573.

(14) Frath, D.; Massue, J.; Ulrich, G.; Ziessel, R. Angew. Chem. Int. Ed. 2014, 53, 2290.

(15) Awuah, S. G.; You, Y. RSC Adv. 2012, 2, 11169.

(16) Kamkaew, A.; Lim, S. H.; Lee, H. B.; Kiew, L. V.; Chung, L. Y.; Burgess, K. Chem. Soc. Rev. 2013, 42, 77.

(17) Lin, H.-Y.; Huang, W.-C.; Chen, Y.-C.; Chou, H.-H.; Hsu, C.-Y.; Lin, J. T.; Lin, H.-W. Chem. Commun. 2012, 48, 8913.

(18) Neto, B. A. D.; Carvalho, P. H. P. R.; Correa, J. R. Acc. Chem. Res. 2015, 48, 1560.

(19) Baker, G. A.; Pandey, S.; Kane, M. A.; Maloney, T. D.; Hartnett, A. M.; Bright, F. V. Biopolymers 2001, 59, 502.

(20) Hansen, A. M.; Sewell, A. L.; Pedersen, R. H.; Long, D.-L.; Gadegaard, N.; Marqueza, R. Tetrahedron 2013, 69, 8527.

(21) Rohand, T.; Qin, W.; Boens, N.; Dehaen, W. Eur. J. Org. Chem. 2006, 2006, 4658.

(22) Descalzo, A. B.; Xu, H.-J.; Shen, Z.; Rurack, K. Ann. N. Y. Acad. Sci. 2008, 1130, 164.

(23) Gomez-Duran, C. F. A.; Esnal, I.; Valois-Escamilla, I.; Urias-Benavides, A.; Banuelos, J.; Lopez Arbeloa, I.; Garcia-Moreno, I.; Pena-Cabrera, E. Chem. - Eur. J. 2016, 22, 1048.

(24) Lu, H.; Mack, J.; Yang, Y.; Shen, Z. Chem. Soc. Rev. 2014, 43, 4778.

(25) Luo, L.; Wu, D.; Li, W.; Zhang, S.; Ma, Y.; Yan, S.; You, J. Org. Lett. 2014, 16, 6080.

(26) Ni, Y.; Wu, J. Org. Biomol. Chem. 2014, 12, 3774.

(27) Poirel, A.; De Nicola, A.; Retailleau, P.; Ziessel, R. J. Org. Chem. 2012, 77, 7512.

(28) Ziessel, R.; Goze, C.; Ulrich, G. Synthesis 2007, 936.

(29) Allen, J. P.; Pfrunder, M. C.; McMurtrie, J. C.; Bottle, S. E.; Blinco, J. P.; Fairfull-Smith, K. E. Eur. J. Org. Chem. 2017, 2017, 476.

(30) del Rio, M.; Lobo, F.; Lopez, J. C.; Oliden, A.; Banuelos, J.; Lopez-Arbeloa, I.; GarciaMoreno, I.; Gomez, A. M. J. Org. Chem. 2017, 82, 1240.

(31) Duran-Sampedro, G.; Agarrabeitia, A. R.; Garcia-Moreno, I.; Gartzia-Rivero, L.; de la Moya, S.; Banuelos, J.; Lopez-Arbeloa, I.; Ortiz, M. J. Chem. Commun. 2015, 51, 11382.

(32) Erbas-Cakmak, S.; Cakmak, F. P.; Topel, S. D.; Uyar, T. B.; Akkaya, E. U. Chem. Commun. 2015, 51, 12258.

(33) Fan, G.; Lin, Y.-X.; Yang, L.; Gao, F.-P.; Zhao, Y.-X.; Qiao, Z.-Y.; Zhao, Q.; Fan, Y.-S.; Chen, Z.; Wang, H. Chem. Commun. 2015, 51, 12447.

(34) Lambert, C.; Scherpf, T.; Ceymann, H.; Schmiedel, A.; Holzapfel, M. J. Am. Chem. Soc. 2015, 137, 3547.

(35) Liras, M.; Iglesias, M.; Sanchez, F. Macromolecules 2016, 49, 1666.

(36) Roedle, A.; Ritschel, B.; Mueck-Lichtenfeld, C.; Stepanenko, V.; Fernandez, G. Chem. Eur. J. 2016, 22, 15772.

(37) Sen, C. P.; Devendar Goud, V.; Shrestha, R. G.; Shrestha, L. K.; Ariga, K.; Valiyaveettil, S. Polym. Chem. 2016, 7, 4213.

(38) Sen, C. P.; Shrestha, R. G.; Shrestha, L. K.; Ariga, K.; Valiyaveettil, S. Chem. - Eur. J. 2015, 21, 17344 . 
Sui, B.; Tang, S.; Woodward, A. W.; Kim, B.; Belfield, K. D. Eur. J. Org. Chem. 2016, $2016,2851$.

(40) Sui, B.; Yue, X.; Kim, B.; Belfield, K. D. ACS Appl. Mater. Interfaces 2015, 7, 17565.

(41) Wanwong, S.; Surawatanawong, P.; Khumsubdee, S.; Kanchanakungwankul, S.; Wootthikanokkhan, J. Heteroat. Chem. 2016, 27, 306.

(42) Yang, W.; Karatay, A.; Zhao, J.; Song, J.; Zhao, L.; Xing, Y.; Zhang, C.; He, C.; Yaglioglu, H. G.; Hayvali, M.; Elmali, A.; Kucukoz, B. Inorg. Chem. 2015, 54, 7492.

(43) Zhong, F.; Karatay, A.; Zhao, L.; Zhao, J.; He, C.; Zhang, C.; Yaglioglu, H. G.; Elmali, A.; Kucukoz, B.; Hayvali, M. Inorg. Chem. 2015, 54, 7803.

(44) Ahrens, J.; Haberlag, B.; Scheja, A.; Tamm, M.; Bröring, M. Chem. - Eur. J. 2014, 20, 2901.

(45) Beh, M. H. R.; Douglas, K. I. B.; House, K. T. E.; Murphy, A. C.; Sinclair, J. S. T.; Thompson, A. Org. Biomol. Chem. 2016, 14, 11473.

(46) Groves, B. R.; Crawford, S. M.; Lundrigan, T.; Matta, C. F.; Sowlati, S.; Thompson, A. Chem. Commun. 2013, 49, 816.

(47) Lundrigan, T.; Baker, A. E. G.; Longobardi, L. E.; Wood, T. E.; Smithen, D. A.; Crawford, S. M.; Cameron, T. S.; Thompson, A. Org. Lett. 2012, 14, 2158.

(48) Lundrigan, T.; Cameron, T. S.; Thompson, A. Chem. Commun. 2014, 50, 7028.

(49) Lundrigan, T.; Crawford, S. M.; Cameron, T. S.; Thompson, A. Chem. Commun. 2012, $48,1003$.

(50) Lundrigan, T.; Thompson, A. J. Org. Chem. 2013, 78, 757.

(51) Antina, E. V.; Guseva, G. B.; Loginova, A. E.; Semeikin, A. S.; V’yugin, A. I. Russ. J. Gen. Chem. 2010, 80, 2374.

(52) Maity, A.; Sarkar, A.; Sil, A.; B. N, S. B.; Patra, S. K. New J. Chem. 2017, 41, 2296.

(53) Ucuncu, M.; Karakus, E.; Emrullahoglu, M. Chem. - Eur. J. 2015, 21, 13201.

(54) Ucuncu, M.; Karakus, E.; Emrullahoglu, M. Chem. Commun. 2016, $52,8247$.

(55) Wan, C.-W.; Burghart, A.; Chen, J.; Bergström, F.; Johansson, L. B. Å.; Wolford, M. F.; Kim, T. G.; Topp, M. R.; Hochstrasser, R. M.; Burgess, K. Chem. Eur. J. 2003, 9, 4430.

(56) Al-Sheikh Ali, A.; Cipot-Wechsler, J.; Crawford, S. M.; Selim, O.; Stoddard, R. L.; Cameron, T. S.; Thompson, A. Can. J. Chem. 2010, 88, 725.

(57) Sanders, D. P.; Connor, E. F.; Grubbs, R. H.; Hung, R. J.; Osborn, B. P.; Chiba, T.; MacDonald, S. A.; Willson, C. G.; Conley, W. Macromolecules 2003, 36, 1534.

(58) Iashin, V.; Chernichenko, K.; Pápai, I.; Repo, T. Angew. Chem. Int. Ed. 2016, 55, 14146.

(59) McGough, J. S.; Butler, S. M.; Cade, I. A.; Ingleson, M. J. Chem. Sci. 2016, 7, 3384.

(60) Leyva-Pérez, A.; Rubio-Marqués, P.; Al-Deyab, S. S.; Al-Resayes, S. I.; Corma, A. ACS Catalysis 2011, 1, 601.

(61) Zhang, X.; Liu, B.; Shu, X.; Gao, Y.; Lv, H.; Zhu, J. J. Org. Chem. 2012, 77, 501.

(62) Brady, P. B.; Carreira, E. M. Org. Lett. 2015, 17, 3350.

(63) Mahdi, T.; Stephan, D. W. Chem. Eur. J. 2015, 21, 11134.

(64) Dureen, M. A.; Brown, C. C.; Stephan, D. W. Organometallics 2010, 29, 6594.

(65) Vitols, S. E.; Roman, J. S.; Ryan, D. E.; Blackwood, M. E. J.; Spiro, T. G. Inorg. Chem. $1997,36,764$.

(66) Abell, A. D.; Litten, J. C.; Nabbs, B. K. Chem. Commun. 1998, 919.

(67) Abell, A. D.; Nabbs, B. K.; Bettersby, A. R. J. Am. Chem. Soc. 1998, 120, 1741.

(68) Melanson, J. A.; Figliola, C.; Smithen, D. A.; Kajetanowicz, A. K.; Thompson, A. Org. Biomol. Chem. 2017, 15, 144.

(69) Thompson, A.; Gao, S.; Modzelewska, G.; Hughes, D. S.; Patrick, B.; Dolphin, D. Org. Lett. 2000, 2, 3587.

(70) Tu, B.; Wang, C.; Ma, J. Org. Prep. Proced. Int. 1999, 31, 349.

(71) Crawford, S. M.; Thompson, A. Org. Lett. 2010, 12, 1424.

(72) Rurack, K.; Kollmannsberger, M.; Daub, J. Angew. Chem. Int. Ed. 2001, 40, 385. 
(73) Fery-Forgues, S.; Lavabre, D. J. Chem. Educ. 1999, 76, 1260. 